\section{Biologia Futura}

https://akademiai.com/loi/019

\section{Original Article}

Cite this article: Cirak $\mathrm{C}$, and Radusiene J. 2019. Factors affecting the variation of bioactive compounds in Hypericum species. Biol. Fut. 70, 198-209.

Received: 14 December 2018

Accepted: 19 July 2019

\section{Keywords:}

abiotic and biotic factors, variation of bioactive compounds, hyperforin, hypericin, Hypericum species

Author for correspondence:

Cuneyt Cirak

e-mail: kalinor27@gmail.com

(C) 2019 Akadémiai Kiadó, Budapest

\title{
Factors affecting the variation of bioactive compounds in Hypericum species
}

\author{
Cuneyt Cirak ${ }^{1}$ and Jolita Radusiene ${ }^{2}$ \\ ${ }^{1}$ Vocational High School of Bafra, Ondokuz Mayis University, Samsun, Turkey \\ ${ }^{2}$ Nature Research Centre, Institute of Botany, Vilnius, Lithuania
}

DOI: $10.1556 / 019.70 .2019 .25$

The genus Hypericum (Hypericaceae) consists of 484 species from 36 sections with worldwide distribution in different areas. Turkey is considered as hot spot for diversity of Hypericum genus. Despite numerous publications, Hypericum species still attracted considerable scientific interest due to pharmaceutically relevant secondary metabolites: naphthodianthrones, acylphloroglucinol derivatives, phenolic acids, flavonoid glycosides, biflavonoids, and some other valuable constituents. Phytochemical investigations carried out on different Hypericum species provided highly heterogeneous results. The content of bioactive compounds varies significantly due to many internal and external factors, including plant organs, phenological stage, genetic profile, environmental abiotic and biotic factors, such as growing site, light, temperature, radiation, soil drought and salinity, pathogens, and herbivores attack. The variations in content of bioactive compounds in plants are regarded as the main problem in the standardization of Hypericum-derived pharmaceuticals and dietary supplements. The review discusses the main factors contributing to the variations of bioactive compounds and what kind of modulations can increase quality of Hypericum raw material.

\section{INTRODUCTION}

Hypericum (Hypericaceae) is one of the 100 largest genera including $22 \%$ of angiosperm diversity (Carine \& Christenhusz, 2010) and consists of 484 species from 36 sections (Crockett \& Robson, 2011). Hypericum species are well-recognized healing agents in folk medicine due to their various pharmaceutical properties. Despite the large number of Hypericum species, only $H$. perforatum L. has been searched deeply to date and its herbal preparations are greatly used as a remedy for the treatment of mild to moderate depression (Fiebich et al., 2011). Turkey is an important extensity center of Hypericum species and Guner et al. (2012) have recently reported the presence of 96 Hypericum species in Turkish flora, 46 of which are endemic. Hypericum species have been used in Turkish traditional medicine under the names "peygamber çiçeği, kantaron, kuzukıran, kanotu, kılıçotu and binbirdelik otu" as wound healing, antiseptics, sedatives, and antispasmodics.

The healing properties of Hypericum plants have prompted investigations of their secondary metabolites and biological activities, which have been mainly attributed to phytochemical groups as naphthodianthrones and phloroglucinol derivatives, phenolic compounds, and essential oils (Zhao et al., 2015). Among the chemical constituents, hypericin and hyperforin were indicated to be synergistically responsible for the antidepressant activity of Hypericum extracts (Kasper et al., 2010, Ramalhete et al., 2016). Antitumor, antiangiogenic (Martinez-Poveda et al., 2005; Rothley et al., 2009; Schiavone et al., 2014), and neuroprotective (Ma et al., 2018) effects were also induced by hyperforin and its derivatives. Extendedly investigated hypericin has been reported to possess antiviral, photodynamic (Shih et al., 2018), antitumor (Kim et al., 2018), and antibacterial activities (Rodriguez-Amigo et al., 2015). Although hyperforin and hypericin have been reported to promote mainly to the bioactivities of Hypericum extracts, several other constituents as phenolic acids and flavonoids have also made a significant contribution to the antidepressant (Tusevski et al., 2018), antimicrobial (Zhao et al., 2010), antioxidant (Alia et al., 2006; Oztürk et al., 2009), and neuroprotective (Silva et al., 2008) activities. Wound-healing activity of Hypericum extracts has been attributed to their accumulation of essential oils. 
Despite numerous studies and publications, Hypericum species are of high-priority research due to the increasing pharmacological significance and commercial value of Hyperici herba, officially obtained from $H$. perforatum (Stojanovic et al., 2013). Thus, a number of Hypericum species from different countries of the world, such as Brazil (França et al., 2013), Greece (Mathioudaki et al., 2018), Italy (Mandrone et al., 2017), Tunisia (Hosni et al., 2017), Serbia, Montenegro (Zdunic et al., 2017), Portugal (Nogueira et al., 2008), Lithuania (Bagdonaite et al., 2010), Jordan (AI-Rifaee et al., 2010), Iran (Pirbalouti et al., 2014), Peru (Ccana-Ccapatinta et al., 2014), and Turkey (Cirak et al., 2016a, 2016b, 2017a, 2017b) have been investigated in respect to the presence of chemical ingredients that give health benefits.

The previous results indicated evident differences referring to accumulation levels of these phytochemicals among different species of Hypericum from various sections (Cirak et al., 2016b); different accessions of the same species from diversified geographic origins (Cirak et al., 2015a; Nogueira et al., 2008), different ontogenetic phases of the same species (Abreu et al., 2004; Cirak et al., 2014b, 2014c) and even among the individuals, cultured under the same controlled environment (Bruni \& Sacchetti, 2009) or regenerated from the same in vitro culture (Ayan et al., 2005). Based on the results, it is not possible to define the exact patterns of synthesis of the main secondary metabolites within and among species of Hypericum genus. Importantly, the data presented in most studies are variable due to different extraction and analysis approaches and are hardly comparable. The chemical heterogeneity of Hypericum species has a remarkable effect on the bioactivity of plant extracts and poses the problem of standardizing of end herbal-derived products (Costa et al., 2016). As a result, the issues on the efficacy and safety of Hypericum-derived pharmaceuticals and dietary supplements have risen. In this context, up to 17-fold and 13-fold differences in hypericin and pseudohypericin amounts, respectively, are reported in several Hypericum-derived commercial products
(Murthy et al., 2014). The first step to be taken to solve this problem is to clarify the main reasons underlying the huge variation in the content and composition of bioactive compounds in Hypericum spp. Thus, based mainly on our previous results and data of other authors, the aim of this study is to discuss the main internal and external impacts on chemical variation to gain a deeper understanding of the regulation of the accumulation of important secondary metabolites in Hypericum species raw materials. In this study, we present our review of relevant data including the past three decades by screening main international online databases, namely, ASABE Technical Library, CAB Abstracts, CAB International E-Books, ProQuest Dissertations and Theses Global, Science Direct, Scopus, Taylor \& Francis Online Journals, Springer E-Book Collection, Web of Science, and JSTOR (Journal Storage).

\section{PLANT ORGAN DEPENDENCE}

Plants of the genus Hypericum are qualified by different types of secretory vesicles, namely translucent glands, black nodules, and secretory canals (Lotocka \& Osinska, 2010). Among Hypericum metabolites, hypericin was reported to accumulate only in the dark glands of plant aerial parts (Fig. 1; Lu et al., 2001; Robson, 2001). In our previous research, we have detected a positive correlation between dark glands number and hypericin content in the leaves of $H$. perforatum, $H$. aviculariifolium Jaup. and Spach subsp. depilatum (Freyn and Bornm.), Robson var. depilatum, $H$. pruinatum Boiss. and Bal. (Cirak et al., 2006b), and H. lydium Boiss (Cirak, 2006). Several authors reported that the lack of hypericin was concerned with the absence of dark glands in the corresponding Hypericum species (Crockett \& Robson, 2011; Nor et al., 2008). It was also shown that the amount of hypericin was negatively correlated with the leaf area of $H$. perforatum (Cirak et al., 2007d).

Recently, hypericin, pseudohypericin and a proposed precursor of hypercins, and emodin were identified not only
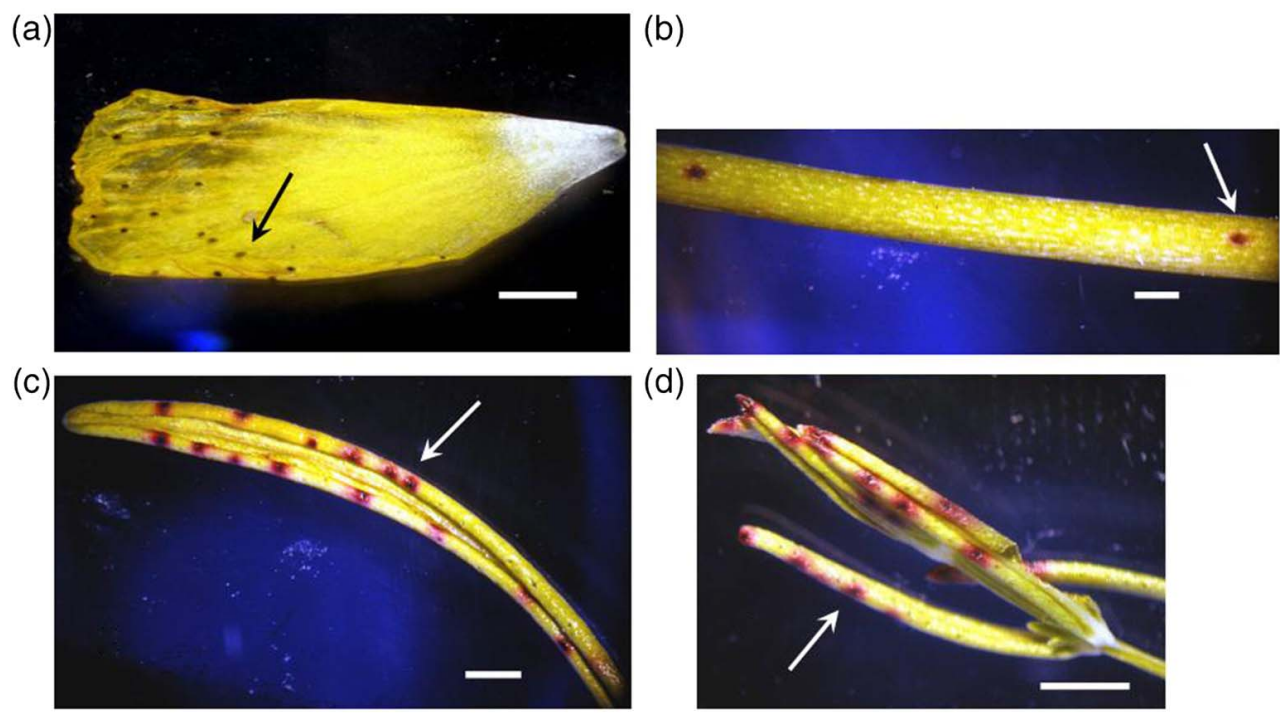

Fig. 1. Dark glands on petal (a), stem (b), and leaves (c, d) of H. lydium (photo by Cirak) 
in dark glands, but also in translucent glands as well as in non-secretory tissues throughout the leaves of some in vitro cultured species from Hypericum section (Kucharíková et al., 2016). According to the chemotaxonomic surveys, hypericins are produced only in phylogenetically advanced clades of the genus as Hypericum, Drosocarpium, Thasia, Adenosepalum (Kitanov, 2001), Olympia (Cirak et al., 2016b), Taeniocarpium, and Drosanthe (Camas et al., 2014b), a result of adaptation to some selective factors. Similarly, essential oils are synthesized either in translucent glands or in secretory canals that may be localized in leaves, flowers including petals, sepals, and pistil (Fig. 2; Zhao et al., 2015). For example, Lotocka and Osinska (2010) reported significant differences in the content and composition of essential oil in leaves and flowers of $H$. elegans Steph. ex Willd., H. inodorum Willd., H. olympicum L., $H$. forrestii (Chitt.) N. Robson and two genotypes of $H$. perforatum. These species highly differed in localization and abundance of the secretory structures and the differences were reported by Zobayed et al. (2006) as the main reason for the variations of phytochemical levels in Hypericum plants. Secretory tissues, despite being present in the whole plant, are mostly located in leaves and reproductive organs, resulting in distinct organ dependence of secondary metabolites. The examples of organ-dependence differences of the pharmacologically important secondary compounds in 36 wild Turkish Hypericum species including subspecies were summarized in Table 1 . The presented data have indicated that floral parts are unique organs for accumulation of hypericins and hyperforins in all Hypericum spp. Biflavonoids seem to be higher in leaves than in flowers for most of the species. Meanwhile, leaves of Hypericum species were exposed to a significant priority in the accumulation of chlorogenic, neochlorogenic, and

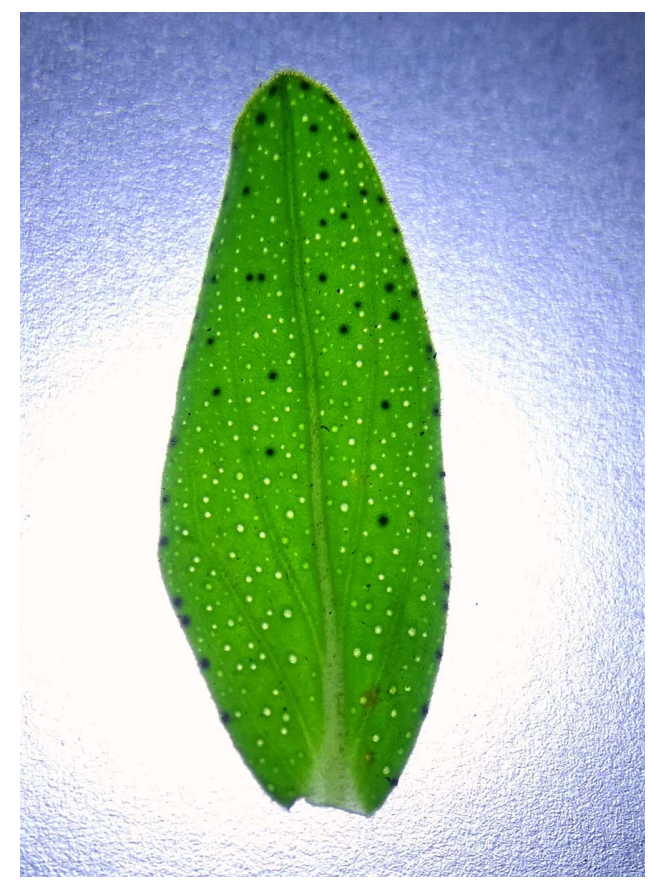

Fig. 2. Dark and transparent glands of $H$. aviculariifolium subsp. depilatum var. depilatum leaf (photo by Cirak C. and Bertoli A. 2013) dihydroxybenzoic acids compared to the inflorescences. As for the presented flavonoids, their maximum levels were provided either in flowers or in leaves, depending on the species.

\section{PHENOLOGY}

The accumulation of bioactive secondary metabolites in different plant organs varied considerably during the seasonal development of plants. Peculiarly, the growth and development of reproductive tissues in Hypericum plants are pursued by speeding of secondary metabolism. The enhanced accumulation of hypericin, hyperforin, phenolic acids, amentoflavone, isoquercitrin, quercitrin, quercetin, avicularin, and catechins was reported during floral development for $H$. perforatum (Cirak et al., 2007b; Kazlauskas \& Bagdonaite, 2004), H. leptophyllum L. (Seyis et al., 2016), H. montbretii Spach. (Cirak et al., 2008c), H. aviculariifolium subsp. depilatum var. depilatum, $H$. orientale L. (Cirak et al., 2013), $H$. origanifolium Wild., H. perfoliatum (Cirak et al., 2007a, 2008a), H. triquetrifolium Turra (Cirak et al., 2014c), H. pruinatum (Cirak et al., 2015c), H. scabrum L. (Ayan et al., 2008), and H. brasiliense Choisy (Abreu et al., 2004). Similarly, the highest yields of essential oil were obtained in $H$. perforatum leaves at flowering and green capsules phases. However, the green capsules and the full opened flowers were different in the composition of essential oil (Bertoli et al., 2011). Schwob et al. (2004) reported that total number of compounds detected in essential oil of $H$. perforatum increased during plant ontogenesis.

Exceptionally, the highest levels of chlorogenic acid, hyperoside, and apigenin-7-O-glucoside accumulation in H. montbretii Spach. (Cirak et al., 2008c), H. origanifolium (Cirak et al., 2007b), H. perfoliatum (Cirak et al., 2007a), and $H$. perforatum (Cirak et al., 2007c) were found in vegetative phase, while the amount of these compounds significantly decreased with the advancement of plant growth. It was detected that the decrease in temperature and light intensity significantly decreased bioactive compounds accumulation during phenological development of H. perforatum (Radusiene et al., 2012). In addition, the relationship between the content of chemical compounds in the plant material of different Hypericum species and the harvesting time was mathematically formulated as $\mathrm{PC}=$ $\left[a+\left(b_{1} \times S\right)+\left(b_{2} \times L\right)+\left(b_{3} \times R\right)+\left(b_{4} \times S^{2}\right)+\left(b_{5} \times(1 / R P)\right]\right.$, where $\mathrm{PC}$ is whole plant content of phenolic compound; $\mathrm{S}$ is phenolic content of stem; $\mathrm{L}$ is phenolic content of leaf; RP is phenolic content of reproductive parts; and $a, b_{1}, b_{2}, b_{3}, b_{4}$, and $b_{5}$ are coefficients. The results of these studies indicate that blooming is the most appropriate harvesting time to provide the highest level of secondary metabolites (Odabas et al., 2008, 2009b). The increasing accumulation of secondary metabolites such as hypericins and phenolic compounds during flowering can be attributed to reproductive adaptations within internal regulation of plant cells to provide protection against plant pathogens and herbivores (Cirak et al., 2014a; Crockett \& Boeve, 2011), higher ultraviolet B (UV-B) radiation, and other environmental stressors during propagule reproduction (Falcone Ferreyra et al., 2012). 


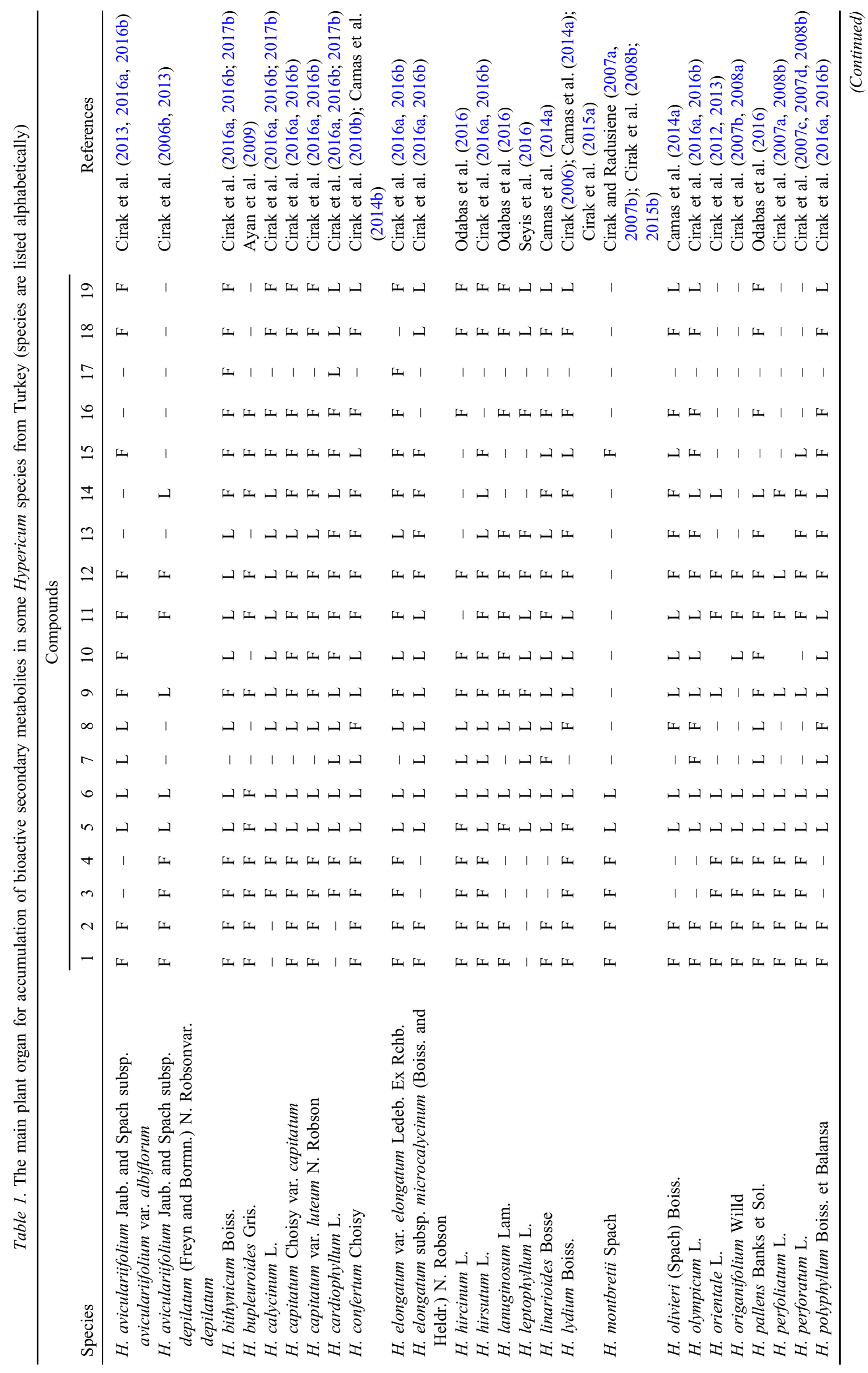


Plants have evolved a broad range of tactics with the aim of protecting themselves against different stressors (Narayani \& Srivastava, 2017), mainly based on induction of new toxic compounds and/or excessive production of preexisting defensive chemicals (Bruce \& Pickett, 2007). Similarly, the induction of various phytochemicals has been reported for the return of biotic challenges in many plant species and a number of bioactive compounds such as hypericin (Crockett \& Boeve, 2011), rutin, and chlorogenic acid (Kroner et al., 2012) have been considered as a chemical defense of plants against plant pathogens and herbivores. Cirak et al. (2005) reported that hypericin level was significantly increased in greenhouse-grown $H$. perforatum and $H$. pruinatum in response to the inoculation of seedlings with the elevating doses of plant pathogens Phytophthora capsici and Diploceras hypericinum. Analogous patterns were reported for $H$. perforatum in the defensive role of hypericin in response to biotic challenge by plant pathogens (Sirvent \& Gibson, 2002) and herbivores (Sirvent et al., 2003). Furthermore, because of the hypericin insecticidal activity, it has been observed that insects feeding on leaves of $H$. perforatum adjust their diet by abstaining from eating the leaf parts containing dark glands in which hypericin is stored (Guillet et al., 2000). Cirak et al. (2006a) observed that hypericin accumulation in H. aviculariifolium subsp. depilatum var. depilatum and $H$. pruinatum significantly increased at night time. The authors attributed the distinct increase of hypericin content in plants to the patterns of nocturnal feeding of destructive insect herbivores.

Among induced secondary metabolites, plant phenolics have an importance in plant defense, and their role in resistance to fungi is more dynamic than their role against insects or any other attacking organisms. It was reported that the content of phenolics such as luteolin, mangiferin, hyperoside, mangostin, isoquercitrine, quercetine, and their derivatives has increased in $H$. perforatum cultures as a response to Colletotrichum gloesporioidies infection, which is one of the most common fungal pathogens inducing bitter rot of many crops (Conceicao et al., 2006). Moreover, Cirak et al. (2014a) described the role of chlorogenic acid, rutin, hyperoside, isoquercetine, quercitrine, and quercetine as part of an inducible plant defense reaction and reported increasing levels of each compound in response to inoculation with the fungal pathogen D. hypericinum and plant growth-promoting bacteria Pseudomonas putida in $H$. perforatum and $H$. triquetrifolium. The enriched accumulation of phenolic compounds has been reported as a genotype response to pathogen infections by upregulation genes-encoding enzymes involved in the phenylpropanoid pathway leading to the synthesis of these compounds (Foster-Hartnettet al., 2007). In the similar way, Crockett and Boeve (2011) have reported an explicit role of flavonoid glycosides in plant defense mechanisms and an increasing accumulation of phenolic compounds in wild growing H. perforatum and H. hirsutum L., as a response to the attack of sawfly (Tenthredo zonula) larvae. 


\section{GROWTH SITE}

The growth site along with the wide range of environmental factors, such as soil, radiation, light, temperature, wind velocity, and others, is known to interfere with the synthesis and accumulation of relevant secondary metabolites in plants. In most of Hypericum species, investigations were conducted using a plant material from wild populations that were exposed to different environments. Significant differences among $H$. perforatum populations were reported for the content of hyperforin, hypericin, and pseudohypericin from Australia (Southwell \& Bourke, 2001), Turkey (Cirak et al., 2006a, 2007d), Lithuania (Bagdonaite et al., 2010), Canada (Jensen et al., 1995), and Armenia (Kirakosyan et al., 2002). Wild populations of other Hypericum species were also reported to display significant variations in the content of several bioactive compounds. In terms of variability of essential oil composition, significant differences were detected in compliance with the geographic distribution of wild populations of $H$. perfoliatum, $H$. humifusum L., H. linarifolium Vahl., and H. pulchrum L. (Nogueira et al., 2008). Cirak and Bertoli (2013) reported significant compositional variations in essential oil between two populations of $H$. aviculariifolium subsp. depilatum var. depilatum. Significant variations were detected in the content of hypericin, pseudohypericin, hyperforin, and several flavonoids as rutin, hyperoside, apigenin-7-Oglucoside, kaempferol, quercitrin, quercetin, and amentoflavone among four wild populations of $H$. triquetrifolium from Turkey (Camas et al., 2008; Cirak et al., 2011). Accordingly, 5 wild populations of $H$. lydium (Cirak et al., 2015a), H. montbretii (Cirak et al., 2015b), and $H$. pruinatum (Camas et al., 2013) and 11 populations of $H$. orientale (Cirak et al., 2012) were significantly different in the quantity of hypericin, pseudohypericin, hyperforin, adhyperforin, chlorogenic acid, neochlorogenic acid, 2,4-dihydroxybenzoic acid, hyperoside, isoquercitrin, quercitrin, quercetin, avicularin, rutin, (+)-catechin and (-)-epicatechin, and amentoflavone.

The results have indicated the importance of the growth localities with different environment characteristics on the expression of secondary metabolites along with the chemical intraspecific diversity of wild Hypericum populations.

\section{ABIOTIC STRESSORS}

\section{Temperature and $U V-B$ radiation}

Among the abiotic stressors of the site, temperature and UV-B radiation have a prominent impact on plant secondary metabolism. Decreased temperature and increased UV-B radiation have caused plant cells to produce reactive oxygen species (ROS) resulting in oxidative damage to lipids, DNA, structural proteins, and other cellular structures. As a result, higher UV-B radiation and lower temperature have stimulated the production of secondary metabolites with UV-Babsorbing and ROS-scavenging qualities, such as phenolic acids, proanthocyanidins, anthocyanins, and flavonoids (Turkan \& Demiral, 2009). Similarly, leaf flavonoid concentrations increased in response to enhancing UV-B radiation in cultivated $H$. perforatum plants (Germ et al., 2010). Abreu and Mazzafera (2005) observed a significant increase in total soluble phenols, rutin, betulinic acid, and quercetin contents in $H$. brasiliense for reaction to low-temperature treatments. Experimentally increased light intensity enhanced the content of leaf hypericin (Briksin \& Gawienowski, 2001; Pardaz et al., 2013) and hyperforin (Odabas et al., 2009a) in $H$. perforatum.

In a similar way, altitude of plant growing site has stimulated secondary metabolism greatly as lower temperature and higher UV-B radiation predominate at higher altitudes. A significant increase in the content of hypericins in $H$. triquetrifolium, $H$. perforatum, $H$. perfoliatum, and $H$. empetrifolium Willd. was reported in response to altitudinal ranging by Xenophontos et al. (2008). Furthermore, Umek et al. (1999) reported a positive correlation between the accumulation of hyperoside, amentoflavone, and rutin and the altitude of habitats of $H$. hirsutum, $H$. perforatum, $H$. maculatum Crantz, $H$. montanum L., $H$. tetrapterum Fries., and $H$. humifusum L. The content of naphtodianthrones, phloroglucinol derivatives and phenolic compounds such as chlorogenic acid, neochlorogenic acid, caffeic acid, 2,4-dihydroxybenzoic acid, 13,II8-biapigenin, hyperoside, isoquercitrin, quercitrin, quercetin, avicularin, rutin, and epicatechins was reported to increase significantly in wild $H$. androsaemum L., $H$. polyphyllum Boiss. and Bal., $H$. orientale and $H$. pallens with elevating altitude of plant growing site (Camas et al., 2014a; Cirak et al., 2017b). The authors attributed the observed increase in content of bioactive compounds in Hypericum species as adaptation to low temperature and high UV-B radiation, which are prevalent at higher altitudes.

\section{Salinity and drought}

Salinity and drought stress are also considered as important abiotic factors influencing growth, productivity, and secondary metabolism of plants, especially in arid and semi-arid regions (Temizel et al., 2014). On top of specific ion effects (salinity stress), nutritional imbalance, and low water potential in a soil solution (drought stress), the detrimental effect of salinity on plant physiology is also related to the production of defensive secondary metabolites (Munns \& Tester, 2008). However, the results of recent studies have indicated that the oxidative stress that could also be caused by drought and the imbalance between the production and elimination of ROS is a major cause of salt sensitivity (Turkan \& Demiral, 2009).

Plants have evolved various defense mechanisms to eliminate the oxidative damage induced by salt and drought stress, which involves the excessive production of antioxidant chemicals that prevent the expansion of oxidative chain reactions. In the circumstances, phenolic compounds such as anthocyanins, phenolic acids, proanthocyanidins, and flavonoids have a significant role in eliminating the impairing effect of salinity (Hichem et al., 2009). The proven antioxidant activity of phenolics allows them to act as ROS-scavenging agents and is the main reason why their 
synthesis is stimulated in return for the exposure to abiotic stresses (Souza \& Devaraj, 2010). The accumulation level of several phenolics namely rutin, quercetin, and total soluble phenols has been significantly enhanced under conditions of water and temperature stresses in greenhouse-grown $H$. brasiliense (Abreu \& Mazzafera, 2005). Moreover, $H$. perforatum plants subjected to drought and salinity stresses exhibited an evident increase in accumulation of total phenolics, quercetin, and rutin (Gray et al., 2003; Temizel 2015). Similarly, hyperforin content in the same species enhanced notably and was nearly double after 12 days of exposure to drought stress (Zobayed et al., 2007). The content of chlorogenic acid, rutin, hyperoside, isoquercetin, quercitrin, and quercetin in $H$. pruinatum plants was also found to be significantly increased by elevating salt treatment doses (Caliskan et al., 2017).

\section{GENOTYPE}

The intraspecific chemical diversity of Hypericum species was reported among wild populations, in plants under controlled conditions and even between the plants regenerated from the same clones in the early stages of development by Kosuth et al. (2003) reporting significant genetic differences between phenotypes. Knowledge about genetic diversity of populations is important for effective germplasm selection and breeding improvement for the desired genotypes. The genetic variations occurring within and among populations of $H$. perforatum and other Hypericum species have been carried out using several molecular analysis methods. Each molecular technique has limitations in the screening of genetic profiles and therefore more than one method should be used to come to a general conclusion. Haluskova and Cellarova (1997) analyzed the somaclonal variation within $H$. perforatum and R1 progenies at the molecular level via restriction fragment length polymorphism (RFLP) technique, whereas Percifield et al. (2007) practiced DNA fingerprinting using amplified fragment length polymorphism (AFLP) technique to search genetic diversity among 11 Hypericum species. Farooq et al. (2014) from India and Morshedloo et al. (2015) from Iran assessed the genetic diversity of $H$. perforatum wild populations from different climatic zones using intersimple sequence repeat markers. Sixteen Tunisian populations of $H$. humifusum L. were evaluated for their genetic variability using isomeric and random-amplified polymorphic DNA (RAPD) markers (Bejaoui et al., 2010, 2012). Furthermore, internal transcribed spacer (Nürk et al., 2013; Pilepic et al., 2011) and RFLP (Pilepic et al., 2010) techniques were used assess the extent of phylogenetic relationships in several sections of Hypericum genus. The following molecular studies have revealed high genetic diversity and excess heterozygosity within populations supporting an outbreeding mating system and low gene flow. On the other hand, different populations of the same species exhibited high genetic similarity and had no obvious relationship with climate zones (Bejaoui et al., 2010). The research by Barcaccia et al. (2006) on genetic diversity and reproductive biology of $H$. perforatum has shown that populations are polyclonal, i.e., not dominated by a single genotype, which is in consequence with the prevalent reproductive mode of facultative apomixes. On the other hand, occasional sexual reproduction leads to genetic diversity that is fixed by apomixis. These genetic findings of the aforementioned authors reflect the chemical variations suggesting that the valuable germplasm of Hypericum spp. can be detected within populations. The chemodiversity that has been identified among populations of the same Hypericum species is likely the result of genetic diversity and adaptive strategies to changing environmental factors.

According to some authors, genetic polymorphism strongly affects the content of bioactive secondary metabolites in Hypericum species (Buter et al., 1998). Cytological and compound accumulation analyses have shown the relationship between the ploidy level and total content of hypericins and phloroglucinols with the highest levels found in diploids and the lowest in tetraploids (Kosuth et al., 2003). However, data about the relationship between the genetic structure and bioactive chemical ingredients in Hypericum spp. are limited and the results from different sources are often quite discrepant. The significant differences in genetic profile together with the differences in the content of chlorogenic acid, rutin, hyperoside, and quercetin were determined by He and Wang (2013) among 12 wild populations of $H$. perforatum in China using sequencerelated amplified polymorphism technique. They observed only a partial correlation between content of bioactive compounds and genetic polymorphism of accessions. Similarly, Verma et al. (2008) reported a partial correlation between hypericins, hyperforin, and flavonoids as rutin, hyperoside, quercitrin, and quercetin contents and data of RAPD and SSR analyses of eight wild $H$. perforatum populations from India. Furthermore, no correlation was found between hypericin content and genetic profile within 27 accessions of $H$. triquetrifolium from Jordan (AI-Rifaee et al., 2010). On the contrary, strong correlations were reported between hypericin content and RAPD data for $19 \mathrm{H}$. perforatum clones cultivated in field conditions during 2 years (Tonk et al., 2011).

The significant correlations between the secondary metabolite contents and RAPD data of the genetic profile were found among different species, namely, $H$. barbatum Jacq., $H$. hirsutum, $H$. linarioides Bosse, $H$. maculatum Crantz, $H$. rumeliacum Boiss., and $H$. tetrapterum Fries, collected from the same site in Serbia (Smelcerovic et al., 2006). In this case, the genotype significantly affects the differences between species, unlike among the accessions of one species. A similar study was conducted with 11 Hypericum species and cultivars that exposed correlations between genetic profiles detected using AFLP technique and levels of hyperforin, hypericins, and rutin in plant materials (Aziz et al., 2006).

\section{CONCLUSION FOR FUTURE BIOLOGY}

Data from the current literature on Hypericum chemistry have revealed that there are major differences in the chemical accumulation levels at the species level. The advantage of this overview is that the plants have been harvested in Turkish territory and evaluated using the same method of extraction and chemical analysis, so the methods did not affect the chemical 
composition and thus make the comparison valid. This way we could show how some endogenous and exogenous factors indeed effect the chemical accumulation of pharmacologically important secondary compounds across many species of Hypericum. Such kind of data provides a firm basis for assessing the primary quality of wild-harvested plant material as well as avoiding the huge chemical variability that is considered as the main obstacle for standardization and further processing of Hypericum-derived products.

\section{Acknowledgments: None.}

Funding Statement: The authors declare that there are no sponsors, no funding, and no conflicts of interest.

Data Accessibility: There are no data sets required for supporting this article.

Competing Interests: The authors declare no competing interests.

Authors' Contributions: CC provided the idea and both authors wrote this paper collectively.

\section{REFERENCES}

Abreu, I. N., Mazzafera, P. (2005) Effect of water and temperature stress on the content of active constituents of Hypericum brasiliense Choisy. Plant Physiol. Biochem. 43, 241-248.

Abreu, I. N., Porto, A. L. M., Marsaioli, A. J., Mazzafera, P. (2004) Distrubution of bioactive substances from Hypericum brasiliense during plant growth. Plant Sci. 167, 949-954.

AI-Rifaee, M. K., Aburjai, T., Haddad, N. (2010, April 18-22) Hypericin from Hypericum triquetrifolium in wild and under cultivation, variation revealed by genetic distance. In 6th Conference on Aromatic and Medicinal Plants of Southeast European Countries (6th CMAPSEEC), Antalya, Turkey.

Alia, M., Mateos, R., Ramos, S., Lecumberri, E., Bravo, L., Goya, L. (2006) Influence of quercetin and rutin on growth and antioxidant defense system of a human hepatoma cell line (HepG2). Eur. J. Nutr. 45, 19-28.

Ayan, A. K., Cirak, C. (2008) Variation of hypericins in Hypericum triquetrifolium Turra growing in different locations of Turkey during plant growth. Nat. Prod. Res. 22, 1597-1604.

Ayan, A. K., Cirak, C., Güney, K. (2008) Seasonal variation of hypericin and pseudohypericin contents in Hypericum scabrum L. growing wild in Turkey. Nat. Prod. Commun. $3,241-244$.

Ayan, A. K., Cirak, C., Kevseroğlu, K., Sökmen, A. (2005) Effects of explant types and different concentrations of sucrose and phytoharmones on plant regeneration and hypericin content in Hypericum perforatum L. Turkish J. Agric. Forest. 29, 197-204.

Ayan, A. K., Cirak, C., Radusiene, J., Janulis, V., Ivanauskas, L. (2009) Secondary metabolites of Hypericum scabrum and Hypericum bupleuroides. Pharm. Biol. 47, 847-853.

Aziz, N., Sauve, R. J., Long, D., Cherry, M. (2006) Genetic and phytochemical diversity assessment among eleven Hypericum accessions via AFLP and HPLC analyses. J. Herbs, Spices Med. Plant. 12, 97-105.

Bagdonaite, E., Martonfi, P., Repcak, M., Labokas, J. (2010) Variation in the contents of pseudohypericin and hypericin in Hypericum perforatum from Lithuania. Biochem. Syst. Ecol. $38,634-640$.

Barcaccia, G., Arzenton, F., Sharbel, T. F., Varotto, S., Parrini, P., Lucchin, M. (2006) Genetic diversity and reproductive biology in ecotypes of the facultative apomict Hypericum perforatum L. Heredity 96, 322-334.

Bejaoui, A., Boulila, A., Messaoud, C., Rejeb, M. N., Boussaid, M. (2010) Genetic diversity and population structure of Hypericum humifusum L. (Hypericaceae) in Tunisia, implications for conservation. Plant Bios. 144, 592-601.

Bejaoui, A., Chokri, M., Mohamed, B. (2012) Genetic structure of natural Tunisian Hypericum humifusum L. (Hypericaceae) populations as assessed by allozymes and RAPDs. Ind. Crop. Prod. 35, 217-223.

Bertoli, A., Cirak, C., Leonardi, M., Seyis, F., Pistell, L. (2011) Morphogenetic changes in essential oil composition of Hypericum perforatum during the course of ontogenesis. Pharm. Biol. 49, 741-751.

Briksin, D. P., Gawienowski, M. C. (2001) Differential effects of light and nitrogen on production of hypericins and leaf glands in Hypericum perforatum. Plant Physiol. Biochem. 39, 1075-1081.

Bruce, T. J. A., Pickett, J. A. (2007) Plant defence signalling induced by biotic attacks. Curr. Opin. Plant Biol. 10, 387-392.

Bruni, R., Sacchetti, G. (2009) Factors affecting polyphenol biosynthesis in wild and field grown St. John's Wort (Hypericum perforatum L. Hypericaceae/Guttiferae). Molecules 14, 682-725.

Buter, B., Orlacchio, C., Soldati, A., Büter, K. B. (1998) Significance of genetic and environmental aspects in the field cultivation of Hypericum perforatum. Planta Med. 64, 431-437.

Caliskan, O., Radusiene, J., Temizel, K. E., Staunis, Z., Cirak, C., Kurt, D., Odabas, M. S. (2017) The effects of salt and drought stress on phenolic accumulation in greenhouse-grown Hypericum pruinatum. Italian J. Agron. 12, 271-275.

Camas, N., Radusiene, J., Ayan, A. K., Cirak, C., Janulis, V., Ivanauskas, L. (2008) Variation of bioactive secondary metabolites in Hypericum triquetrifolium Turra from wild populations of Turkey. Nat. Prod. Commun. 3, 1713-1717.

Camas, N., Radusiene, J., Cirak, C., Stanius, Z., Odabas, M. S., Çalışkan, Ö. (2013) Chemical composition of Hypericum pruinatum Boiss. and Bal. from wild populations of Northern Turkey. Res. Pharm. 3, 14-21.

Camas, N., Radusiene, J., Ivanauskas, L., Jakstas, V., Cirak, C. (2014a) Altitudinal changes in the content of bioactive substances in Hypericum orientale and Hypericum pallens. Acta Physiol. Plant. 36, 675-686.

Camas, N., Radusiene, J., Ivanauskas, L., Jakstas, V., Kayıkçı, S., Cirak, C. (2014b) Chemical composition of Hypericum species from the Taeniocarpium and Drosanthe sections. Plant Syst. Evol. 300, 953-960.

Carine, M. A., Christenhusz, M. J. M. (2010) About this volume, the monograph of Hypericum by Norman Robson. Phytotaxa $4,1-4$.

Ccana-Ccapatinta, G. V., Stolz, E. D., da Costa, P. F., Rates, S. M., von Poser, G. L. (2014) Acylphloroglucinol derivatives from 
Hypericum andinum, antidepressant-like activity of andinin A. J. Nat. Prod. 77, 2321-2325.

Cirak, C. (2006) Hypericin in Hypericum lydium Boiss. growing in Turkey. Biochem. Syst. Ecol. 34, 897-899.

Cirak, C., Aksoy, H. M., Ayan, A. K., Saglam, B., Kevseroglu, K. (2005) Enhanced hypericin production in Hypericum perforatum and Hypericum pruinatum in response to inoculation with two fungal pathogens. Plant Prot. Sci. 41, 109-114.

Cirak, C., Ayan, A. K., Kevseroğlu, K., Özen, T. (2006a) Variation of hypericin in St. John's wort (Hypericum perforatum) from wild population of Northern Turkey. Acta Bot. Hung. 48, 55-64.

Cirak, C., Bertoli, A. (2013) Aromatic profiling of wild and rare species growing in Turkey, Hypericum aviculariifolium Jaub. and Spach subsp. depilatum (Freyn and Bornm.) Robson var. depilatum and Hypericum pruinatum Boiss. and Bal. Nat. Prod. Res. 27, 100-107.

Cirak, C., Bertoli, A., Pistelli, L., Seyis, F. (2010a) Essential oil composition and variability of Hypericum perforatum from wild populations of northern Turkey. Pharm. Biol. 48, 906-914.

Cirak, C., Kurt, D. (2014) Hypericum species as important medicinal plants. J. Anadolu Ege Agric. Res. Inst. 24, 42-58.

Cirak, C., Radusiene, J. (2007a) Variation of hyperforin in Hypericum montbretii during its phenological cycle. Nat. Prod. Res. 21, 1151-1156.

Cirak, C., Radusiene, J. (2007b) Hypericins in Hypericum montbretii, variation among plant parts and phenological stages. Med. Aromat. Plant. Sci. Biotechnol. 1(2), 253-256.

Cirak, C., Radusiene, J., Aksoy, H. M., Mackinaite, R., Stanius, Z., Camas, N., Odabas, M. S. (2014a) Differential phenolic accumulation in two Hypericum species in response to inoculation with Diploceras hypericinum and Pseudomonas putida. Plant Prot. Sci. 50, 119-128.

Cirak, C., Radusiene, J., Camas, N. (2008a) Pseudohypericin and hyperforin in two Turkish Hypericum species, variation among plant parts and phenological stages. Biochem. Syst. Ecol. 36, 377-382.

Cirak, C., Radusiene, J., Camas, N., Çalışkan, Ö., Odabas, M. S. (2013) Changes in the contents of main secondary metabolites in two Turkish Hypericum species during plant development. Pharm. Biol. 51, 391-399.

Cirak, C., Radusiene, J., Ivanauskas, L., Jakstas, V., Camas, N. (2014b) Phenological changes in the chemical content of wild and greenhouse-grown Hypericum pruinatum, Flavonoids. Turkish J. Agric. Forest. 38, 362-370.

Cirak, C., Radusiene, J., Ivanauskas, L., Jakstas, V., Camas, N. (2015a) Population variability of main secondary metabolites in Hypericum lydium Boiss. (Hypericaceae). Iranian J. Pharm. Res. 14, 969-978.

Cirak, C., Radusiene, J., Ivanauskas, L., Jakstas, V., Camas, N. (2015b) Changes in the content of bioactive substances among Hypericum montbretii Spach (Hypericaceae) populations from Turkey. Brazilian J. Pharmacogn. 24, 20-24.

Cirak, C., Radusiene, J., Ivanauskas, L., Jakstas, V., Camas, N., Kurt, D. (2015c) Phenological changes in the chemical content of wild and greenhouse-grown Hypericum pruinatum, hypericins, hyperforins and phenolic acids. Res. Rev. J. Botany 4, $37-47$.

Cirak, C., Radusiene, J., Jakstas, V., Ivanauskas, L., Seyis, F., Yayla, F. (2016a). Secondary metabolites of seven Hypericum species growing in Turkey. Pharm. Biol. 54, 2244-2253.
Cirak, C., Radusiene, J., Janulis, V., Ivanauskas, L. (2007a) Secondary metabolites in Hypericum perfoliatum, variation among plant parts and phenological stages. Bot. Helv. 117, 29-36.

Cirak, C., Radusiene, J., Janulis, V., Ivanauskas, L. (2007b) Variation of bioactive secondary metabolites in Hypericum origanifolium during its phenological cycle. Acta Physiol. Plant. 29, 197-203.

Cirak, C., Radusiene, J., Janulis, V., Ivanauskas, L. (2008b) Pseudohypericin and hyperforin in Hypericum perforatum from Northern of Turkey, variation among populations, plant parts and phenological stages. J. Integr. Plant Biol. 50, 575-580.

Cirak, C., Radusiene, J., Janulis, V., Ivanauskas, L. (2010b) Secondary metabolites of Hypericum confertum and their possible chemotaxonomic significance. Nat. Prod. Commun. 5, 897-898.

Cirak, C., Radusiene, J., Janulis, V., Ivanauskas, L., Camas, N., Ayan, A. K. (2011) Phenolic constituents of Hypericum triquetrifolium Turra (Guttiferae) growing in Turkey, variation among populations and plant parts. Turkish J. Biol. 35, 449-457.

Cirak, C., Radusiene, J., Jakstas, V., Ivanauskas, L., Seyis, F., Yayla, F. (2017a) Altitudinal changes in secondary metabolite contents of Hypericum androsaemum and Hypericum polyphyllum. Biochem. Syst. Ecol. 70, 108-115.

Cirak, C., Radusiene, J., Jakstas, V., Ivanauskas, L., Yayla, F., Kurt, D. (2017b) Amentoflavone and mangiferin in Hypericum calycinum, Hypericum cardiophyllum and Hypericum bithynicum. Res. Rev. J. Herbal Sci. 6, 10-13.

Cirak, C., Radusiene, J., Jakstas, V., Ivanauskas, L., Yayla, F., Seyis, F., Camas, N. (2016b). Secondary metabolites of Hypericum species from the Drosanthe and Olympia sections. S. Afr. J. Bot. 104, 82-90.

Cirak, C., Radusiene, J., Karabük, B., Janulis, V., Ivanauskas, L. (2007c) Variation of bioactive compounds in Hypericum perforatum growing in Turkey during its phenological cycle. J. Integr. Plant Biol. 49, 615-620.

Cirak, C., Radusiene, J., Karpaviciene, B., Camas, N., Odabas, M. S. (2014c) Changes in phenolic content of wild and greenhouse-grown Hypericum triquetrifolium during plant development. Turkish J. Agric. Forest. 37, 307-314.

Cirak, C., Radusiene, J., Sağlam, B. (2008c) Variation of bioactive substances in Hypericum montbretii during plant growth. Nat. Prod. Res. 22, 246-252.

Cirak, C., Radusiene, J., Sağlam, B., Janulis, V. (2007d) Variation of bioactive substances and morphological traits in Hypericum perforatum populations from Northern Turkey. Biochem. Syst. Ecol. 35, 403-409.

Cirak, C., Radusiene, J., Stanius, Z., Camas, N., Çalışkan, Ö., Odabas, M. S. (2012) Secondary metabolites of Hypericum orientale $\mathrm{L}$. growing in Turkey, variation among populations and plant parts. Acta Physiol. Plant. 34, 1313-1320.

Cirak, C., Saglam, B., Ayan, A. K., Kevseroğlu, K. (2006b) Morphogenetic and diurnal variation of hypericin in some Hypericum species from Turkey during the course of ontogenesis. Biochem. Syst. Ecol. 34, 1-13.

Conceicao, L. F. R., Ferreres, F., Tavares, R. M., Dias, A. C. P. (2006) Induction of phenolic compounds in Hypericum perforatum L. cells by Colletotrichum gloeosporioides elicitation. Phytochemistry 67, 149-155. 
Costa, J., Campos, B., Amaral, J. S., Nunes, M. E., Oliveira, B. P. P., Isabella, M. (2016) HRM analysis targeting ITS1 and matK loci as potential DNA mini-barcodes for the authentication of Hypericum perforatum and Hypericum androsaemum in herbal infusions. Food Control 61, 105-114.

Crockett, S. L., Boeve, J. L. (2011) Flavonoid glycosides and naphthodianthrones in the sawfly Tenthredo zonula and its host-plants, Hypericum perforatum and H. hirsutum. J. Chem. Ecol. 37, 943-52.

Crockett, S. L., Robson, N. K. B. (2011) Taxonomy and chemotaxonomy of the genus Hypericum. Hypericum. Med. Aromat. Plant Sci. Biotechnol. 5(Special Issue 1), 1-13.

Falcone Ferreyra, M. L., Rius, S. P., Casati, P. (2012) Flavonoids, biosynthesis, biological functions, and biotechnological applications. Front. Plant. Sci. 3, 1-15.

Farooq, S., Siddiqui, M. A., Ray, P. C., Sheikh, M. Q., Shahnawaz, S., Bhat, M. A., Mir, M. R., Abdin, M. Z., Ahmad, I., Javid, J., Yadav, P., Masroor, M., Zuberi, M., Saxena, A., Mir, R. (2014) Genetic diversity analysis in the Hypericum perforatum populations in the Kashmir valley by using inter-simple sequence repeats (ISSR) markers. Afr. J. Biotechnol. 13, 18-31.

Fiebich, B. L., Knörle, R., Apel, K., Kammler, T., Weiss, G. (2011) Pharmacological studies in an herbal drug combination of St. John's wort (Hypericum perforatum) and passion flower (Passiflora incarnata): In vitro and in vivo evidence of synergy between Hypericum and Passiflora in antidepressant pharmacological models. Fitoterapia 82, 474-480.

Foster-Hartnett, D., Danesh, D., Penuel, S., Sharopova, N., Endre, G., Vandenbosch, K. A., Young, N. D., Samac, D. A. (2007) Molecular and cytological responses of Medicago truncatula to Erysiphe pisi. Mol. Plant Pathol. 8, 307-319.

França, H. S., Rocha, L., Fernande, C. P., Ruiz, A. L. T. G., de Carvalho, J. E. (2013) Antiproliferative activity of the hexanic extract and phloroglucinols from Hypericum brasiliense. Rev. Bras. Farmacogn. 23, 844-847.

Germ, M., Stibilj, V., Kreft, S., Gaberscik, A., Kreft, I. (2010) Flavonoid, tannin and hypericin concentrations in the leaves of St. John's wort (Hypericum perforatum L.) are affected by UV-B radiation levels. Food Chem. 122, 471-474.

Gray, D. E., Pallardy, S. G., Garrett, H. E. (2003) Effect of acute drought stress and time of harvest on phytochemistry and dry weight of St. John's wort leaves and flowers. Planta Med. 69, 1024-1030.

Guillet, G., Podeszfinski, C., Regnault-Roger, J., Arnason, T., Philogene, B. J. R. (2000) Behavioral and biochemical adaptations of generalist and specialist herbivorous insects feeding on Hypericum perforatum (Guttiferae). Environ. Entomol. 29, $135-139$.

Guner, A., Aslan, S., Ekim, T., Vural, M., Babaç, M. T. (2012) List of Turkish flora (vascular plants). İstanbul, Turkey: Nezahat Gökyiğit Botanical Garden and Flora Research Foundation. Retrieved from http://www.bizimbitkiler.org.tr/v2/hiyerarsi. php?c=Hypericum

Haluskova, J., Cellarova, E. (1997) RFLP analysis of Hypericum perforatum L. somaclones and their progenies. Euphytica 95, 229-235.

He, M., Wang, Z. (2013) Genetic diversity of Hypericum perforatum collected from the Qinling Mountains of China. Biochem. Syst. Ecol. 50, 232-239.

Hichem, H., Mounir, D., Naceur, E. A. (2009) Differential responses of two maize (Zea mays L.) varieties to salt stress, changes on polyphenols composition of foliage and oxidative damages. Ind. Crop. Prod. 30, 144-151.

Hosni, K., Msaâda, K., Taârit, M. B., Marzouk, B. (2017) Fatty acid composition and tocopherol content in four Tunisian Hypericum species, Hypericum perforatum, Hypericum tomentosum, Hypericum perfoliatum and Hypericum ericoides subsp. Roberti. Arab. J. Chem. 10, 2736-2741.

Jensen, K. I. N., Gaul, O. S., Specth, E. G., Doohan, D. J. (1995) Hypericin content of Nova Scotia genotypes of Hypericum perforatum L. Can. J. Plant Sci. 75, 923-926.

Kasper, S., Caraci, F., Forti, B., Drago, F., Aguglia, E. (2010) Efficacy and tolerability of Hypericum extract for the treatment of mild to moderate depression. Eur. Neuropsychopharm. 20, 74-765.

Kazlauskas, S., Bagdonaite, E. (2004) Quantitative analysis of active substances in St. John's wort (Hypericum perforatum L.) by the high performance liquid chromatography method. Medicina (Kaunas) 40, 975-981.

Kim, H., Kim, S. W., Seok, K. H., Hwang, C. W., Ahn, J. C., Jin, J., Kang, H. W. (2018) Hypericin-assisted photodynamic therapy against anaplastic thyroid cancer. Photodiagn. Photodyn. 24, 15-21.

Kirakosyan, A., Gibson, D., Sirvent, T. (2002) Comperative survey of Hypericum perforatum plants as sources of hypericins and hyperforin. J. Herbs, Species Med. Plant. 10, 110-122.

Kitanov, M. K. (2001) Hypericin and pseudohypericin in some Hypericum species. Biochem. Syst. Ecol. 29, 171-178.

Kosuth, J., Koperdakova, J., Tolonen, A., Hohtola, A., Cellarova, E. (2003) The content of hypericins and phloroglucinols in Hypericum perforatum L. seedlings at early stage of development. Plant. Sci. 165, 515-521.

Kroner, A., Marnet, N., Andrivon, D., Val, F. (2012) Nicotiflorin, rutin and chlorogenic acid, phenylpropanoids involved differently in quantitative resistance of potato tubers to biotrophic and necrotrophic pathogens. Plant Physiol. Biochem. $57,23-31$.

Kucharíková, A., Kusari, S., Sezgin, S., Spiteller, M., Čellárová, E. (2016) Occurrence and distribution of phytochemicals in the leaves of 17 in vitro cultured Hypericum spp. adapted to outdoor conditions. Front. Plant Sci. 7, 1616.

Lotocka, B., Osinska, E. (2010) Shoot anatomy and secretory structures in Hypericum species (Hypericaceae). Bot. J. Linean. Soc. 163, 70-86.

Lu, H. F., Shen, Z. G., Li, J. Y. H., Hu, Z. H. (2001) The patterns of secretory structure and their relation to hypericin content in Hypericum. Acta Bot. Sin. 43, 1085-1088.

Ma, L., Pan, X., Zhou, F., Liu, K., Wang, L. (2018) Hyperforin protects against acute cerebral ischemic injury through inhibition of interleukin-17A-mediated microglial activation. Brain Res. 1678, 254-261.

Mandrone, M., Scognamiglio, M., Fiorentino, A., Sanna, C., Cornioli, L., Antognoni, F., Bonvicini, F., Poli, F. (2017) Phytochemical profile and $\alpha$-glucosidase inhibitory activity of Sardinian Hypericum scruglii and Hypericum hircinum. Fitoterapia 120, 184-193.

Martinez-Poveda, B., Quesada, A. R., Medina, M. A. (2005) Hyperforin, a bio-active compound of St. John'sWort, is a new inhibitor of angiogenesis targeting several key steps of the process. Int. J. Cancer 117, 775-780.

Mathioudaki, A., Berzesta, A., Kypriotakis, Z., Skaltsa, H., Heilmann, J. (2018) Phenolic metabolites from Hypericum 
kelleri Bald., an endemic species of Crete (Greece) Phytochemistry 146, 1-7.

Morshedloo, M. R., Moghadam, M. R. F., Ebadi, A., Yazdani, D. (2015) Genetic relationships of Iranian Hypericum perforatum L. wild populations as evaluated by ISSR markers. Plant Syst. Evol. 301, 657-665.

Munns, R., Tester, M. (2008) Mechanisms of salinity tolerance. Annual Rev. Plant Biol. 59, 651-681.

Murthy, H. N., Kim, Y. S., Park, S. Y., Paek, K. Y. (2014) Hypericin, biotechnological production from cell and organ cultures. Appl. Microbiol. Biotechnol. 98, 9187-9198.

Narayani, M., Srivastava, S. (2017) Elicitation, a stimulation of stress in in vitro plant cell/tissue cultures for enhancement of secondary metabolite production. Phytochem. Rev. 16, 1227-1252.

Nogueira, T. M. J., Marcelo-Curto, A., Figueiredo, C., Barroso, J. G., Pedro, L. G., Rubiolo, P., Bicchi, C. (2008) Chemotaxonomy of Hypericum genus from Portugal, geographical distribution and essential oils composition of Hypericum perfoliatum, Hypericum humifusum, Hypericum linarifolium and Hypericum pulchrum. Biochem. Syst. Ecol. 36, 40-50.

Nor, C., Bernardi, A. P. M., Haas, J. S., Schripsema, J., Rech, S. B., von Poser, G. L. (2008) Phenolic constituents of Hypericum flowers. Nat. Prod. Commun. 3, 237-240.

Nürk, N. M., Madrinan, S., Carine, M. A., Chased, M. W., Blattnera, F. R. (2013) Molecular phylogenetics and morphological evolution of St. John's wort (Hypericum; Hypericaceae). Mol. Phylogenet. Evol. 66, 1-16.

Odabas, M. S., Radusiene, J., Cirak, C., Camas, N. (2008) Prediction models for the phenolic contents in some Hypericum species from Turkey. Asian J. Chem. 20, 4792-4802.

Odabas, M.S., Radusiene, J., Çamaş, N., Janulis, V., Ivanauskas, L., Cirak, C. (2009a) The quantitative effects of temperature and light intensity on hyperforin and hypericins accumulation in Hypericum perforatum L. J. Med. Plant Res. 3, 519-525.

Odabas, M. S., Radusiene, J., Cirak, C., Camas, N. (2009b) Models of estimation of the content of secondary metabolites in some Hypericum species. Pharm. Biol. 47, 1117-1122.

Odabas, M. S., Radusiene, J., Ivanauskas, L., Jakstas, V., Camas, N., Kayikci, S. (2016) Secondary metabolites of Hypericum hircinum, Hypericum pallens, Hypericum russeggeri and Hypericum lanuginosum. Zemdirbyste 103, 193-198.

Oztürk, N., Tunçel, M., Erkara, I. P. (2009) Phenolic compounds and antioxidant activities of some Hypericum species, A comparative study with $H$. perforatum. Pharm. Biol. 47, $120-127$.

Pardaz, J. E., Shakiba, M. R., Toorchi, M., Mohammadinasab, A. D. (2013) The influence of light intensities and nitrogen on growth of Hypericum perforatum L. Int. J. Agric. Res. Rev. 3, 775-781.

Percifield, R. J., Hawkins, J. S., McCoy, J. A., Widrlechner, M. P., Wendel, J. F. (2007) Genetic diversity in Hypericum and AFLP markers for species-specific identification of $H$. perforatum $\mathrm{L}$. Planta Med. 73, 1614-1621.

Pilepic, K. H., Balic, M., Blazina, M. (2011) Estimation of phylogenetic relationships among some Hypericum (Hypericaceae) species using internal transcribed spacer sequences. Plant Biosyst. 145, 81-87.

Pilepic, K. H., Morovic, M., Orac, F., Santor, M., Vejnovi, V. (2010) RFLP analysis of cpDNA in the genus Hypericum. Biologia 65, 805-812.

Pirbalouti, A. G., Fatahi-Vanani, M., Craker, L., Shirmardi, H. (2014) Chemical composition and bioactivity of essential oils of Hypericum helianthemoides, Hypericum perforatum and Hypericum scabrum. Pharm. Biol. 52, 175-181.

Radusiene, J., Karpaviciene, B., Stanius, Z. (2012) Effect of external and internal factors on secondary metabolites accumulation in St. John's worth. Bot. Lith. 18, 101-108.

Ramalhete, N., Machado, A., Serrano, R., Gomes, E. T., MotaFilipe, H., Silva, O. (2016) Comparative study on the in vivo antidepressant activities of the Portuguese Hypericum foliosum, Hypericum androsaemum and Hypericum perforatum medicinal plants. Ind. Crop. Prod 82, 29-36.

Robson, N. K. B. (2001) Studies in the genus Hypericum L. (Guttiferae). Bull Br Mus (Nat Hist) Bot 8, 55-226.

Rodriguez-Amigo, B., Delcanale, P., Rotger, G., Juárez-Jiménez, J., Viappiani, C. (2015) The complex of hypericin with $\beta$ lactoglobulin has antimicrobial activity with potential applications in dairy industry. J Dairy Sci. 98, 89-94.

Rothley, M., Schmid, A., Thiele, W., Schacht, V., Plaumann, D., Gartner, M., Yektaoglu, A., Bruyère, F., Noël, A., Giannis, G., Sleeman, J. P. (2009) Hyperforin and aristoforin inhibit lymphatic endothelial cell proliferation in vitro and suppress tumor-induced lymph angiogenesis in vivo. Int. J. Cancer 125, 34-42.

Schiavone, B. I. P., Verotta, L., Rosato, A., Marilena, M., Gibbons, S., Bombardelli, E., Franchini, C., Corbo, F. (2004) Changes in essential oil composition in Saint John's wort (Hypericum perforatum L.) aerial parts during its phenological cycle. Biochem. Syst. Ecol. 32, 735-745.

Schiavone, B. I. P., Verotta, L., Rosato, A., Marilena, M., Gibbons, S., Bombardelli, E., Franchini, C., Corbo, F. (2014) Anticancer and antibacterial activity of hyperforin and its derivatives. Anticancer Agents Med. Chem. 14, 1397-1401.

Schwob, I., Bessiere, J. M., Masotti, V., Viano, J. (2004) Changes in essential oil composition in Saint John's wort (Hypericum perforatum L.) aerial parts during its phenological cycle. Biochem. Syst. Ecol. 32, 735-745.

Seyis, F., Radusiene, J., Jakstas, V., Ivanauskas, L., Cirak, C. (2016) Morphogenetic and phenological changes in phenolic content of Hypericum leptophyllum, an endemic Turkish species. Israel J. Plant Sci. 63, 96-104.

Shih, C. M., Wu, C. H., Wu, W. J., Hsiao, Y. M., Ko, J. L. (2018) Hypericin inhibits hepatitis $\mathrm{C}$ virus replication via deacetylation and down-regulation of heme oxygenase-1. Phytomedicine 46, 193-198.

Silva, B., Oliveira, P. J., Dias, A., Malva, J. O. (2008) Quercetin, kaempferol and biapigenin from Hypericum perforatum are neuroprotective against excitotoxic insults. Neurotox. Res. 13, 265-279.

Sirvent, T., Gibson, D. (2002) Induction of hypericins and hyperforin in Hypericum perforatum L. in response to biotic and chemical elicitors. Physiol. Mol. Plant Pathol. 60, 311-320.

Sirvent, T., Stuart, B., Donna, G. (2003) Induction of hypericins and hyperforins in Hypericum perforatum in response to damage by herbivores. J. Chem. Ecol. 29, 2667-2681.

Smelcerovic, A., Verma, V., Spiteller, M., Ahmad, S. M., Puri, S. C., Qazi, G. N. (2006) Phytochemical analysis and genetic characterization of six Hypericum species from Serbia. Phytochemistry 67, 171-177.

Southwell, I. A., Bourke, C. A. (2001) Seasonal variation in hypericin content of Hypericum perforatum L. (St. John's wort). Phytochemistry 56, 437-441. 
Souza, M. R. D., Devaraj, V. R. (2010) Biochemical responses of Hyacinth bean (Lablab purpureus) to salinity stress. Acta Physiol. Plant. 32, 341-353.

Spiteller, M., Özen, T., Smelcerovic, A., Zuehlke, S., MimicaDukić, N. (2008) Phenolic constituents and the in vitro antioxidant activity of the flowers of Hypericum venustum. Fitoterapia 79, 191-193.

Stojanovic, G., Dordevic, A., Smelcerovic, A. (2013) Do other Hypericum species have medical potential as St. John's Wort (Hypericum perforatum)? Curr. Med. Chem. 20, 2273-2295.

Temizel, K. E. (2015) Estimation of the phenolics content of St. John's wort (Hypericum perforatum L.) grown under different water and salt levels based on reflectance spectroscopy. Kuwait J. Sci. 42, 210-222.

Temizel, K. E., Odabas, M. S., Senyer, N., Kayhan, G., Bajwa, G. S., Caliskan, O., Ergun, E. (2014) Comparision of some models for estimation of reflectance of Hypericum leaves under stress conditions. Cent. Eur. J. Biol. 9, 1226-1234.

Toker, Z. (2009) Variation of total hypericin, phenolic and flavonoid compounds in Hypericum triquetrifolium during its phenological cycle. Pharm. Biol. 47, 285-288.

Tonk, F. A., Giachino, R. R. A., Sönmez, Ç., Yüce, S., Bayram, E., Telci, İ., Furan, M. A. (2011) Characterization of various Hypericum perforatum clones by hypericin and RAPD analyses. Int. J. Agric. Biol. 13, 31-37.

Turkan, I., Demiral, T. (2009) Recent developments in understanding salinity tolerance. Environ. Exp. Bot. 67, 2-6.

Tusevski, O., Krstikj, M., Stanoeva, J. P., Stefova, M., Simic, S. G. (2018) Phenolic profile and biological activity of Hypericum perforatum L., can roots be considered as a new source of natural compounds? S. Afr. J. Bot. 117, 301-310.

Umek, A., Kreft, S., Kartnig, T., Heydel, B. (1999) Quantitative phytochemical analysis of six Hypericum species growing in Slovenia. Planta Med. 65, 388-390.

Verma, V., Smelcerovic, A., Zuehlke, S., Hussain, M. A., Ahmad, S. M., Ziebach, T., Qazi, G. N., Spiteller, M. (2008) Phenolic constituents and genetic profile of Hypericum perforatum L. from India. Biochem. Syst. Ecol. 36, 201-206.

Xenophontos, M., Stavropoulos, I., Avramakis, E., Navakoudis, E., Dörnemann, D., Kotzabasis, K. (2008) Influence of the habitat altitude on the (proto)hypericin and (proto)pseudohypericin levels of Hypericum plants from Crete. Planta Med. 74, 1496-1503.

Zhao, J., Liu, W., Wang, J. (2015) Recent advances regarding constituents and bioactivities of plants from the genus Hypericum. Chem. Biodivers. 12, 309-349.

Zhao, M., Wang, H., Yang, B., Tao, H. (2010) Identification of cyclodextrin inclusion complex of chlorogenic acid and its antimicrobial activity. Food Chem. 120, 1138-1142.

Zobayed, S. M. A., Afreen, F., Kozai, T. (2007) Phytochemical and physiological changes in the leaves of St. John's wort plants under a drought stress condition. Environ. Exp. Bot. 59, 109-116.

Zobayed, S. M. A., Freen, F. A., Goto, E., Kozai, T. (2006) Plantenvironment interactions, accumulation of hypericin in dark glands of Hypericum perforatum. Ann. Bot. 98, 793-804.

Zdunic, G., Godjevac, D., Savikin, K., Petrovic, S. (2017) Comparative analysis of phenolic compounds in seven Hypericum species and their antioxidant properties. Nat. Prod. Commun. $12,1805-1811$. 